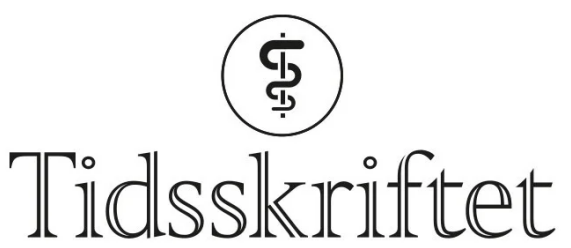

DEN NORSKE LEGEFORENING

\title{
Ramadan under covid-19-pandemien
}

DEBATT

\section{SHERAZ YAQUB}

sheraz.yaqub@ous-hf.no

Sheraz Yaqub er dr.med., FEBS og overlege ved Seksjon for lever- og pankreaskirurgi, Oslo universitetssykehus.

Forfatteren har fylt ut ICMJE-skjemaet og oppgir ingen interessekonflikter.

\section{MOHAMMAD USMAN RANA}

Mohammad Usman Rana er lege i spesialisering ved Øre-nese-halsavdelingen, Oslo universitetssykehus.

Forfatteren har fylt ut ICMJE-skjemaet og oppgir ingen interessekonflikter.

\section{PÅL AUKRUST}

Pål Aukrust er dr.med. og professor ved Seksjon for klinisk immunologi og infeksjonssykdommer, Oslo universitetssykehus.

Forfatteren har fylt ut ICMJE-skjemaet og oppgir ingen interessekonflikter.

\section{Ramadan er i gang. Hvilke råd bør vi gi pasienter i risikosonen som ønsker å faste?}

Det er ca. 200 ooo muslimer bosatt i Norge (1). I ramadanmåneden er alle friske voksne muslimer pålagt å faste fra daggry (suhur) til solnedgang (iftar). I år startet ramadan 24. april og avsluttes med markering av id-al-fitr 24. mai.

Covid-19-pandemien har ført til at mange pasienter og leger lurer på om det er trygt å gjennomføre fasten i år.

\section{Risiko ved faste og covid-19}

Det foreligger per i dag ingen dokumentasjon på at det å faste i seg selv øker risikoen for å få virusinfeksjoner, inkludert covid-19 (르). Det er foreløpig heller ingen studier på forløpet av covid-19 hos fastende personer. Barn og gravide samt personer med kronisk sykdom som diabetes mellitus, nyresvikt, hjerte- og lungesykdom og kreftsykdom er i islam allerede fritatt fra å faste. Disse pasientene har økt risiko for alvorlig forløp av covid-19 (3-5). Det samme gjelder alder over 65 år. For friske personer i denne aldersgruppen bør helsepersonell gjøre en helhetsvurdering i samråd med pasienten. Det er ekstra viktig 
under pandemien at helsepersonell som behandler/kontrollerer pasienter med alvorlige sykdommer eller høy alder, aktivt tar opp fasting under ramadan. Ved indikasjon bør pasientene anbefales å avstå fra å faste.

\section{Dehydrering og risiko for covid-19}

De fastende vil ikke ha noe væskeinntak i 16-18 timer. Selv om det vil føre til forbigående dehydrering, er det svært lite sannsynlig at det vil føre til kronisk eller alvorlig dehydrering hos friske personer. Videre er dehydrering et større problem i land med varmere klima enn Norge. Ut fra vår kunnskap foreligger det ingen dokumentasjon på at forbigående dehydrering eller tørre slimhinner øker risikoen for å få covid-19 eller få et alvorligere forløp hvis man blir smittet. Vi anbefaler at fastende personer får i seg 2-4 liter væske mellom fastetidspunktene (solnedgang til soloppgang). I pandemiens startfase i vestlige land sirkulerte det i sosiale medier råd om at hyppig vanninntak skulle forhindre infeksjon. Denne påstanden er imidlertid ikke dokumentert, og hygienetiltak og avstand til andre spiller etter vår oppfatning en mye viktigere rolle.

\section{Felles iftar og bønn}

Under ramadan i år er alle moskeer stengt, og det er svært viktig å minne om at selv om det er tradisjon for å ha felles fastebrytningsmåltid og felles kveldsbønn, kan ikke, ifølge rådene per månedsskiftet april/mai, flere enn fem personer (unntatt de som bor i husholdningen) møtes. De skal i tillegg holde 1-2 meters avstand til hverandre. Aller helst bør en unngå slike samlinger så langt det lar seg gjøre. Det er et vesentlig poeng at i islam er det å bevare egen og andres helse et sentralt påbud. Muslimske trossamfunn i hele verden, inkludert Norge, har kansellert religiøse samlinger og viser til at hindring av smitte også er en religiøs gjerning og god dyd.

\section{Fordeler ved fasting}

Flere studier viser at intermitterende fasting, som ved ramadan, har positive metabolske

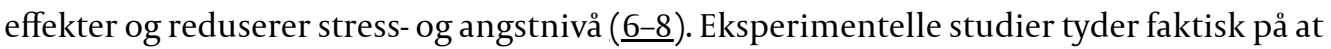
fasting kan ha en gunstig effekt på immunapparatet (9).

\section{Oppsummering}

Det foreligger ingen dokumentasjon på at friske individer har økt risiko for å bli smittet av covid-19 eller utvikle alvorlig sykdom grunnet intermitterende fasting i ramadanmåneden. Imidlertid anbefaler vi at helsepersonell aktivt tar opp fasting med sine pasienter. De som får symptomer på covid-19, skal da kontakte helsepersonell og eventuelt bryte fasten, og personer med alvorlig kronisk eller akutt sykdom skal avstå fra å faste, noen det er gitt åpning for i religionen. Til slutt må man repetere smitteverntiltak og anbefale å unngå sosialisering selv om det er en viktig tradisjon i ramadan.

\section{"Vi anbefaler at helsepersonell aktivt tar opp fasting med sine pasienter»}

Det bør generelt stilles krav til dokumentasjon hva gjelder nytteeffekten av råd som gis. Hvis ikke, kan vi risikere at viktige virkningsfulle tiltak mot covid-19- som god håndhygiene, sosial distansering og at smittede skal isolere seg - vannes ut $\mathrm{i}$ 
informasjonsstrømmen. Det foregår stor forskningsaktivitet for å kartlegge ulike aspekter ved pandemien, og vi ser frem til at det også vil komme klarere forskningsbaserte råd vedrørende fasting. Uansett ønsker vi alle en god ramadan.

\section{LITTERATUR}

1. SSB. 4 prosent muslimer i Norge? https://www.ssb.no/befolkning/artikler-og-publikasjoner/4prosent-muslimer-i-norge--329115 Lest 27.4.2020.

2. Salem M, Jahrami H, Madkour M et al. Ramadan intermittent fasting and immunity: An important topic in the era of COVID-19. Annals of Thoracic Medicine 2020. Pre-proof.

3. Zheng Z, Peng F, Xu B et al. Risk factors of critical \& mortal COVID-19 cases: A systematic literature review and meta-analysis. J Infect 2020; 80: So163-4453(20)30234-6. [PubMed][CrossRef]

4. Onder G, Rezza G, Brusaferro S. Case-fatality rate and characteristics of patients dying in relation to COVID-19 in Italy. JAMA 2020;323. doi: 10.1001/jama.2020.4683. [PubMed][CrossRef]

5. World Health Organization. Safe Ramadan practices in the context of the COVID-19: interim guidance. https://apps.who.int/iris/handle/10665/331767 Lest 27.4.2020.

6. Cho Y, Hong N, Kim KW et al. The effectiveness of intermittent fasting to reduce body mass index and glucose metabolism: A systematic review and meta-analysis. J Clin Med 2019; 8: E1645. [PubMed] [CrossRef]

7. Adawi M, Watad A, Brown S et al. Ramadan fasting exerts immunomodulatory effects: Insights from a systematic review. Front Immunol 2017; 8: 1144. [PubMed][CrossRef]

8. Leiper JB, Molla AM, Molla AM. Effects on health of fluid restriction during fasting in Ramadan. Eur J Clin Nutr 2003; 57 (Suppl 2): S30-8. [PubMed][CrossRef]

9. Bordon Y. Fast tracking immunity. Nat Rev Immunol 2019; 19: 598. [PubMed][CrossRef]

Publisert: 5. mai 2020. Tidsskr Nor Legeforen. DOI: 10.4045/tidsskr.20.0390

Mottatt 28.4.2020, første revisjon innsendt 30.4.2020, godkjent 4.5.2020.

(C) Tidsskrift for Den norske legeforening 2023. Lastet ned fra tidsskriftet.no 26. april 2023. 